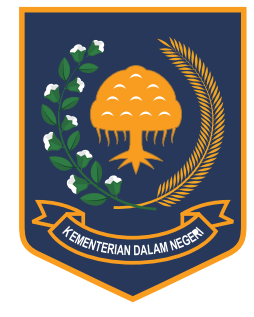

Jurnal Bina Praja 9 (1) (2017): 15-27

Jurnal Bina Praja

e-ISSN: 2503-3360 | p-ISSN: 2085-4323

Accreditation Number

735/AU2/P2MI-LIPI/04/2016

http://jurnal.kemendagri.go.id/index.php/jbp/index

\title{
Authoritative Agency for TOURISM Zone: AN INNOVATIVE INSTRUMENT FOR DESTINATION DEVELOPMENT?
}

\author{
Benjamin Abdurahman * \\ LEKAD, Lembaga Pengembangan dan Pemberdayaan Kerja Sama Antar Daerah \\ AETI Purwokerto Office, PCW Complex Block B No. 12 \\ Jl. HR. Bunyamin Purwokerto - Indonesia
}

Received: 25 November 2016; Accepted: 26 March 2017; Published online: 31 May 2017

DOI: $10.21787 / \mathrm{jbp} .09 .2017 .15-27$

\begin{abstract}
Authority confusion in a development area in the region, especially on tourism destinations, has increased the government's attention. The weaknesses of communication, coordination, and cooperation (3K) across sectors are suspected to be the source of the inhibiting problem. The actors who have various authorities run less synergistically and sometimes tend to prioritize their sector ego. The Ministry of Tourism currently prioritizes the concept of single destination - single management that is believed to answer the problem of development of tourism destinations in Indonesia. Ten tourism destinations have been established into national priority destinations as well as being the focus and locus of implementing this concept. To that end, the government through the Ministry of Tourism encourages the birth of institutions that have an integrity of authority, namely in the form of Tourism Authority Agency (BOP). But there are still other patterns that can be held, such as Destination Management Organization (DMO) in the context of Destination Governance (DG). The discussion of the concept of BOP as an instrument of tourism destination development in the region became the focus of writing this article. A discussion on BOP concept management pattern with DMO also needs to be done to be the source of consideration for policy improvement and planning for central and regional in the future.
\end{abstract}

Keywords: Destination Governance, Destination Management

\section{INTRODUCTION}

Indonesia is a country rich in cultural diversity, ethnicity, and natural beauty with various tourism destinations. The World Economic Forum report shows that Indonesia's tourism position is now ranked 50th in the world, from its previous 70th position. However, Indonesia's position is still less than that of neighboring Singapore (11), Malaysia (25), and Thailand (35). In the news (Metrotvnews. com, 2016), presented a portrait of Indonesia's tourism development, especially in the aspect of sustainability development, which is ranked 130 out of 144 countries of the world. This situation means there are still a lot of homework to be done in order to improve the competitiveness of Indonesian tourism. As one of tourism destination countries, Indonesia has a lot of destinations with a lot of tourist attractions, public facilities, tourism facilities, accessibility, and the community that must be interconnected and complementary. Therefore, one of the keys to successful tourism is the success of tourism destination area management.

In terms of management (institutional) of tourism in Indonesia, especially in destinations, there are various patterns of application. In the context of participatory community management for example, according to Nawawi (2013), can be seen in the village of Parangtritis, Bantul regency. Community participation in the management of Parangtritis beach tourism as evidenced by the establishment of Tourism Cooperative Mina Bahari 45 Depok Beach. Such participatory management encourages the strengthening of the effective arrangement and setup of trading places, the location of food stalls, and managers of tourist attractions. Thus, 'empowerment' is one of the keywords in the implementation of participatory management. Another example of the form of management by empowering the community

\footnotetext{
* Corresponding Author

Phone : +62812 88009968

Email : benrahman@yahoo.com
} 
Table 1.

Foreign Exchange of Asian Tourism Comparison (in million USD)

\begin{tabular}{ccccc} 
Ranking & Country & 2013 & 2014 & 2015 \\
1 & China & 51,664 & 56,913 & 114,109 \\
\hline 2 & Thailand & 42,080 & 38,437 & 44,553 \\
\hline- & Hong Kong, SAR & 38,940 & 38,376 & 36,150 \\
\hline 3 & Malaysia & 21,496 & 21,820 & 17,597 \\
\hline 4 & Singapore & 19,301 & 16,743 \\
\hline 5 & India & 18,397 & 19,203 & 24,013 \\
\hline 6 & Japan & 15,131 & 18,700 & 15,285 \\
\hline 7 & South Korea & 14,629 & 18,147 & 14,406 \\
\hline 9 & Taiwan & 12,323 & 14,618 & 12,578 \\
\hline 10 & Indonesia & 10,054 & 11,166 & 7,301 \\
\hline
\end{tabular}

Source: UNWTO Tourism Highlights, 2016 Edition

economically according to Dewi (2013) is in the area of tourism attraction, such as Tanah Lot located in Beraban Village, Bali.

On the scale of management of destination areas that are relatively broad and have strategic value, especially nationally, then central intervention becomes important. This is relevant, given the complexity of sector and agency linkages that require governance systems that meet the needs and demands of development and extension of destinations. The effect of the central intervention is not only limited to the aspects of regulation/ policy and planning, but also in the institutional context. Until now the spatial structural approach still dominates as a central policy choice, namely through the utilization of the concept of KSPN and SEZ. To measure the effectiveness of this approach, it should be seen from one indicator of success in bringing tourists from time to time.

Reflecting on the experience of the practice of destination areas management abroad, there are some that show better performance than in Indonesia in the aspect of foreign tourists visiting. For example, countries that have world-class cultural destinations (world heritage sites), such as India shows average visits to the Taj Mahal of 3 million (Nationalgeographic.com, 2010), while Cambodia with Angkor Wat attracted 2.1 million (Chandara, 2016). On the other hand, based on the statement of Head of Marketing Department of PT.
TWC Borobudur Prambanan and Ratu Boko, Emelia Eny Utari, she revealed the number of foreign tourists visiting Borobudur, Prambanan, and Ratu Boko temples were 466,935 in 2015 (Razak, 2016).

Based on Table 1, can be illustrated that the income of Indonesia's foreign exchange is ranked ninth, only half of Malaysia and one-quarter of Thailand.

Various policies have been made by the government, especially through the Ministry of Tourism, in response to the problem of tourism competitiveness of Indonesia. From significant budget additions to promotion to success in promoting relevant sectors, particularly in the areas of transportation, immigration, facilities, and infrastructure at the central level. Currently, the government has also decided to strengthen the capacity of the destination area as an effort to accelerate the improvement of national tourism competitiveness. Since the end of 2014 , has been introduced 10 priority destination areas to work with the hope to be the spearhead as well as a model of development and management, especially in the context of tourism destinations. Looking at the learning from the past, the government chose to promote the concept of single destination - single management. The concept is applied in the form of the Tourism Authority Board (BOP) and is expected to answer the problems of overlapping tupoksi (main duty and function) and authority between 


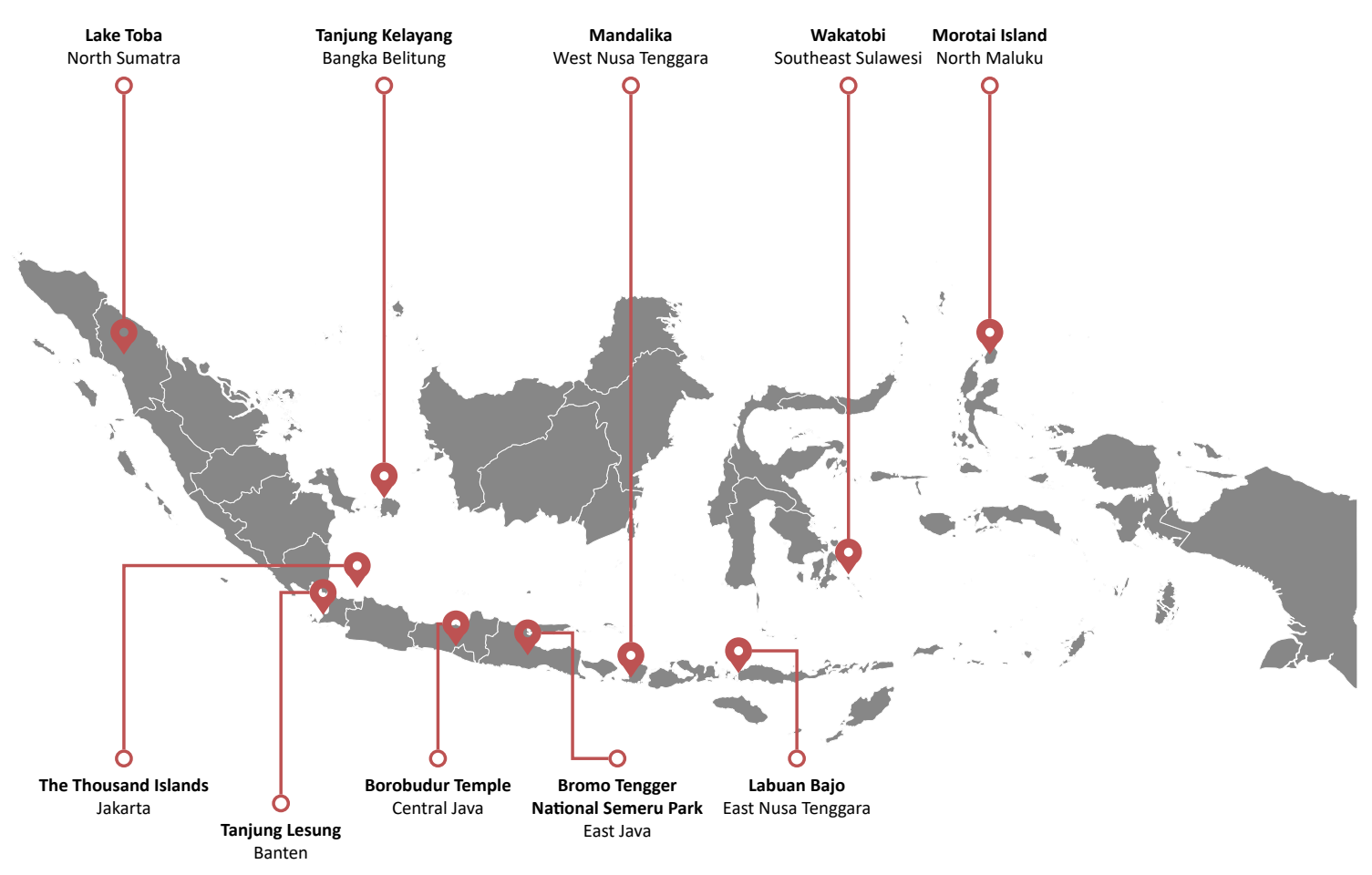

Figure 1. 10 Indonesia's Priority Tourism Destination Locations

Source: Ministry of Tourism, 2016

sectors and stakeholders. This concept replaces the multi-management pattern that has been considered to burden the management of tourism destinations. Conceptually, the BOP will manage the destination end-to-end.

Currently, 10 National Strategic Tourism Areas (KSPN) have been designated as national priority tourism destinations: Lake Toba (North Sumatra), Tanjung Kelayang (Belitung), Tanjung Lesung (Banten), Kota Tua Jakarta - Kepulauan Seribu (DKI), Borobudur Central Java), Bromo-TenggerSemeru (Jatim), Mandalika (Lombok), Komodo Island of Labuan Bajo (NTT), Wakatobi (Sultra) and Morotai (Maltara). Of the ten destinations, there are 4 areas that have special economic zones (SEZ), namely Tanjung Kelayang SEZ, Tanjung Lesung SEZ, Mandalika, and Morotai. Thus, the pattern of the Tourism Authority Board is not applied to the four regions but to the other 6 KSPNs.

On the other hand, the Ministry of Tourism, through Tourism Destination Governance Program since the last few years, has been socializing the concept of DMO on 25 KSPNs. As an approach, DMO is understood as 'an instrument to bring together the interests of tourists with managers and between stakeholders and stakeholders in tourism destinations' (Ministry of Tourism, 2014). DMO practice is not separated from the approach of governance of destinations involving many parties in an integrated system. This approach is intended to strengthen tourism destination system through interconnection, linkage, and tourism destination chain. DMO as the realization of Destination Governance is characterized by the involvement of the parties directed to the aspect of synergy as a destination governance system. Characteristics of this approach are dynamic, organizational, and behavioral structures, a cooperation of sectors, business, local authority, and individual in a system and network analysis. Dimensions of DMO management and DG approach with its basic principles and characteristic are dominated by nonstructural patterns (Abdurahman, 2014a, p. 5).

Comparison of institutional pattern utilization dominated by structural dimension (public sector), such as SEZ and BOP with DMO based on nonstructural management dimension become the focus of this study. The characteristic of each institutional pattern thus needs to be systematically displayed, so the differences that impact on the realization of the concept can be clearly seen. Understanding of each institutional pattern and its management dimension is needed to find solutions to communication, coordination, and cooperation (3K) weaknesses in the governance of development areas - including in the tourism context. As a closing to the conclusion, the innovative idea of tourism destination management is presented as an advanced discourse material, as well as consideration of central and local policies in the future. 


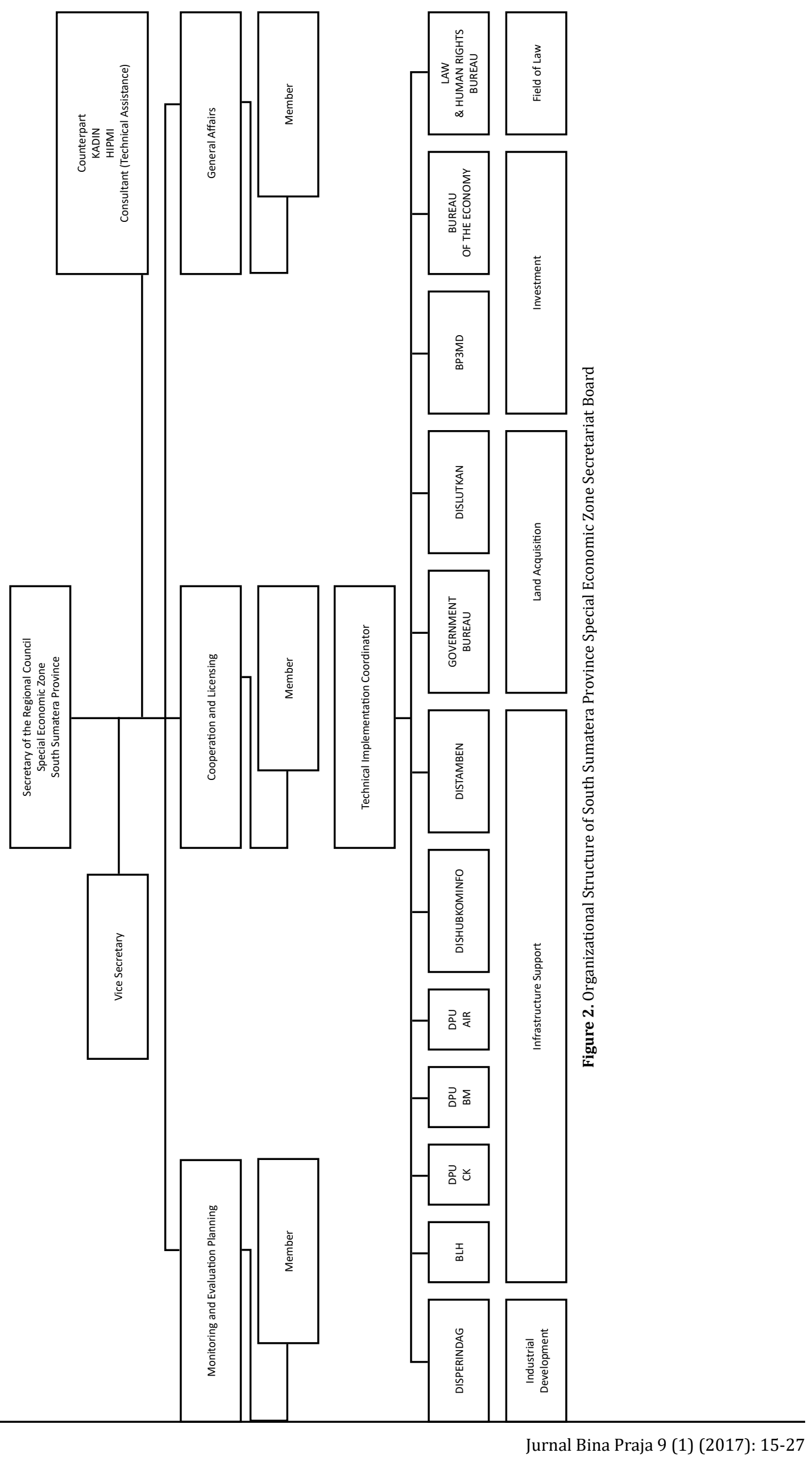




\section{METHOD}

The implementation of the research in this study includes the type of descriptive-normative research that is explorative. Descriptive research that is explorative aims to describe the state or status of phenomena (Arikunto, 2006). While the purpose of this normative research as a practical science is to change the circumstances and offer solutions to social problems that are concrete and potential (Ibrahim, 2005, p. 293). In this case, the authors explore and identify matters relating to SEZ, BOP, and DMO as Innovative Instruments for Destinations Development.

The data collection in this study uses techniques of (1) documentation, (2) observation, and (3) interviews and discussions. In addition, the results of field observations during the process of planning, drafting, forming, and implementing the concept of integrated area management in various areas - including the patterned Destination Management Organization (DMO) - by researchers, have become one of the empirical foundations in this study. In analyzing the data, the authors used a qualitative descriptive analysis. Descriptive method is a method in examining the status of a group of people, an object, a set of conditions, a system of thought, or a class of events in the present time (Nazir, 2000: 63).

To complement the comprehensive portrait of integrated area management, it is deemed necessary to see the practice of utilizing the concept of integrated development abroad (China and Africa) as a benchmarking. Through the analysis of the institutional concept used, found the relevant characteristics and then categorized systematically. Institutional groupings in the structural, nonstructural, and market management dimensions (Abdurahman, 2005, 2014b) and characteristic groupings between SEZ, BOP, and DMO (Table 2) are conducted in order to analyze the weaknesses and advantages of each management pattern. It also shows the originality of the study results, where the characteristics of each management dimension are clearly displayed.

\section{RESULTS AND DISCUSSION}

\section{A. Dynamics of Integrated Area Management in Indonesia}

In accordance with Law Number 23 of 2014 on Regional Government, what referred to as special areas include Free trade areas and/or free ports, authorized areas, special economic zones, and so forth. Institutionalization of its implementation can be seen through various forms. Since the journey of the new order has been known, Batam Authority Agency, which is now the Batam Enterprises Agency,
Integrated Economic Development Zone (KAPET) until now in the form of Special Economic Zones (SEZ). KAPET is present through Decree of the President of the Republic of Indonesia Number 150 of 2000 on Integrated Economic Development Zone. But along with the birth of Indonesian Presidential Regulation Number 176 of 2014, then the entire KAPET has been disbanded. Authority Agency (BO) formed by Decree of the President of the Republic of Indonesia Number 41 of 1973 on Batam Island Industrial Area transformed into Batam Enterprises under the Coordinating Ministry for Economic Affairs of the Republic of Indonesia. This institutional position in the future will be authorized in the form of SEZ.

The utilization of SEZ in an international context is known as Special Economic Zone (SEZ). This approach is seen as one of the efforts to attract foreign investment that is expected to create jobs. Based on comparative advantage (especially cheap labor), expected to occur a development extension through the industrial sector. However, the Indonesian legislation establishes SEZ 'through the preparation of geo-economic and geostrategic areas and serves to accommodate industrial activities, exports, imports, and other economic activities of high economic value and international competitiveness' (Law of the Republic of Indonesia Number 39 of 2009 on Special Economic Zones., 2009, Chapter II, Article 2). Currently, there are 9 SEZs that are being developed by the government through Coordinating Minister for Economic Affairs. Among them are 4 SEZs that focus on developing the tourism function, namely Tanjung Kelayang, Tanjung Lesung, and Mandalika and Morotai which also focus on fishery processing, business, and logistics industry.

The existence of SEZ cannot be separated from the institutional aspect, especially the management institution which has the authority of development and the extension of the region. The institutional model of SEZ in Indonesia is similar to that of KAPET in the past which has distinctive characteristics of management, namely structural, bureaucratic, formal with 'directive' coordination from above. Structural-hierarchical management is characterized in part by the existence of the National Council at the central and the Council of Regions in the area held by elements of the public sector.

The components of Business Entities and administrators are what 'can' or should be filled by elements of noncivil servants, especially from professionals. However, in reality, the regions tend to use civil servants in the composition of SEZ management personnel. This example can be seen in the Simalungun District Regulation Number 4 of 2014 on the Organization and Work Procedure Administrator of Special Economic Zones Sei 
Mangkei Simalungun, where all relevant personnel come from civil servants. This condition is not surprising given that the region has a role model from the central government, where personnel is placed on the structure of the SEZ National Council, including the Implementing Team, and entirely dominated by structural elements. This condition proves the strong structural-bureaucratic pattern used from central to local level. Another example of the structural characteristics in SEZ management in the Region can be observed in Figure 2.

Noting the organizational chart of the Secretariat of the Regional Zone Council based on the Decision of the Governor of South Sumatera Number 790/KPTS/BAPPEDA/2014 above, there is KADIN, HIPMI, and Consultant as counterparts. This partner element is not listed and described in the framework of the membership of the secretariat of the SEZ Regional Council on the Decision of the Governor of South Sumatra dated 30 August 2014. It can be concluded that the role and function of the partner are to provide input and not as an active element participating in the process of decision management and making.

From learning in the international context, as is the case with some SEZs in China, it demonstrates a range of critical success factors (Zeng, 2015), namely (1) strong government commitment and support in reforming regulations for market-oriented, (2) land reform (i.e. certification Ownership and certainty of land functions through spatial planning), (3) incentives and autonomy of regional management, (4) 'Foreign Direct Investment and the Chinese diaspora' policy, (5) strengthening of science and technology on domestic economy, (6) openness and attractiveness for Skilled migrants, (7) the concept of competitive regional development, and (8) strategic geographic location. Very relevant in the institutional discussion here is in point 3 above, which is related to website autonomy management. It turns out that competent professionals play a Materials: role in carrying out the operationalization of the area.

On the other hand, the learning implementation of SEZ pattern in Africa according to Zeng (2012) recommended improvement of 1) Legal aspects, regulation, and institutional framework, 2) conducive business climate, 3) Strategic planning and utilization of demand-driven approach, 4) Infrastructure; Especially roads, water, electricity, and the internet, 5) Expertise in the operationalization of area management, and 6) Handling of population evictions. In line with these findings, Jose Rizal Damuri of the Center for Strategic and International Studies (CSIS) discusses the eight issues and challenges of SEZ development in Indonesia, among others: 1) Institutional Structure, 2) Inter-agency Coordination, 3) Certainty of incentive and regulatory system, 4) Infrastructure, 5) Location consideration, 6) Access to market, 7) Employment aspect, 8) location and land issues.

The findings of the SEZ implementation studies in both international and domestic contexts show the urgency to make breakthroughs in order to optimize the performance of SEZ in Indonesia. Based on the report of United Nations Industrial Development Organization (2015), the competitive industrial performance (CIP) ranking of Indonesia ranks 42 out of 130 countries, far below Singapore which is now ranked 7 th and Malaysia 24th. This should become a trigger for Indonesia in making various improvements, especially in utilizing the SEZ as an instrument to strengthen competitiveness worldwide.

\section{B. Agency Authority as a Model of Area Management}

In history, the utilization of $\mathrm{BO}$ as an institutional model can be observed in Batam, Riau Islands Province. In its journey, the issue of overlapping authority between BO and Batam City Government becomes one of the main issues. Since the implementation of regional autonomy, the friction of the implementation of the main tasks and functions are increasingly real. One of the striking problems of is on lucrative licensing and levy aspects for investors. Synchronization, harmonization, and assertiveness of regulatory reform should be implemented. Various implementation polemics of BO in Batam will certainly continue as long as the legal product improvement is not done. Legal firmness is needed to build investor and public confidence. Extending the existence of the BO with institutional improvement efforts without improving regulatory umbrella is feared will only become a 'time bomb' that burdens the coordination and synchronization of regional development.

Regardless of the dynamics of the utilization of BO which is now transformed into Batam Enterprises Agency (BP Batam), now comes the concept of the Authority Management Agency (BOP) of Tourism for national priority KSPN. The issuance of Indonesian Presidential Regulation Number 49 of 2016 on Tourism Area Management Authority of Lake Toba, marks the utilization of institutional model of BOP as a manager of tourism area in Lake Toba. In the context of the management dimension, the BOP of Lake Toba Tourism Area is basically the same as SEZ which has the working area boundaries (enclaves). BOP as a product of policy is born through formal-bureaucratic planning mechanism which in this case is stipulated in the form of Presidential Regulation. One of the classic weaknesses of formal bureaucratic planning is unilinear (gradual flow from problem identification to implementation) with relatively narrow planning 


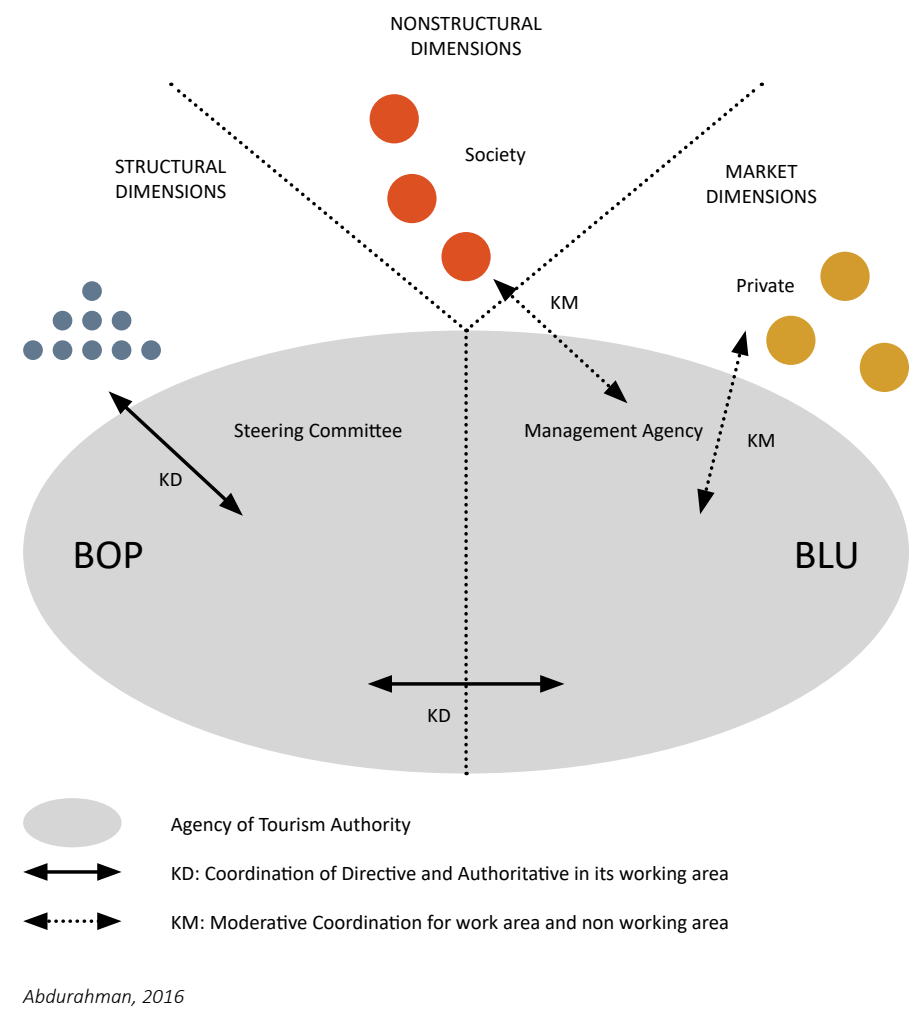

Figure 3. Integration of 2 Management Dimension in the Context of Lake Toba and Its Surroundings BOP

time limits. It is not surprising that in the final stage, which is the implementation, it is potential to gain resistance from the stakeholders in the region. In the case of Lake Toba, can be observed in the statement of attitudes of local leaders in North Sumatra signed on 22 June 2016. In the statement of attitudes, listed a call to revise the Presidential Regulation, in particular with regards to the preservation of Lake Toba and forests around the area as well as the protection of local communities (PGI-Berita Gereja, 2016).

The process of establishing Tourism BOP in other KSPNs, such as Borobudur and Wakatobi and its surroundings, is also inseparable from various challenges, such as land issues and evictions, friction among communities (Dwi, 2016), and local government authority. People in Wakatobi, on the other hand, are worried about the negative impact of the BO (Fikri, 2016). Regardless of the pros and cons of a regulatory or policy product, it should be considered and understood as the dynamics of management utilization on a structural dimension rooted in development mechanisms based on democracy. The process of decision-making on the principle of democracy refers to the majority system as a policy controller. Participation mechanisms from stakeholders are here to provide input rather than in the context of taking decisions. Ultimately, the government through its structural institutions ensures the content and direction of the policy in question. Basically, changes, improvements, and revisions can only be done on the structural dimension. In a democratic system, those called regulators are people who are in the executive and legislative positions as the maker of law and policy products (Baldwin, Cave, \& Lodge, 2011).

Thus, understanding the meaning of participation in formal-bureaucratic planning, in which in addition to the executive and legislative, is certainly not as the party to determine/ensure a product of policy. In other words, participation in the structural management dimension means: involving stakeholders to be heard, recorded, and discussed as input and consideration in the preparation of regulatory/policy products. The economist and legendary political scholar Schumpeter stated, "The democratic method is that the institutional arrangement for arriving at political decisions which realize the common good by making the people of itself." (Schumpeter, 1976). The consequence is that the will of the majority becomes the determining factor in the decisionmaking process of elected representatives. There is no guarantee that the proposals and opinions collected from 'participatory' inputs will be either partially or fully followed. In the end, it depends on the regulators in taking their attitude and decision.

In short, BOP is ensured to be a product of structural dimension through an inherent procedure with a directive coordination pattern. 


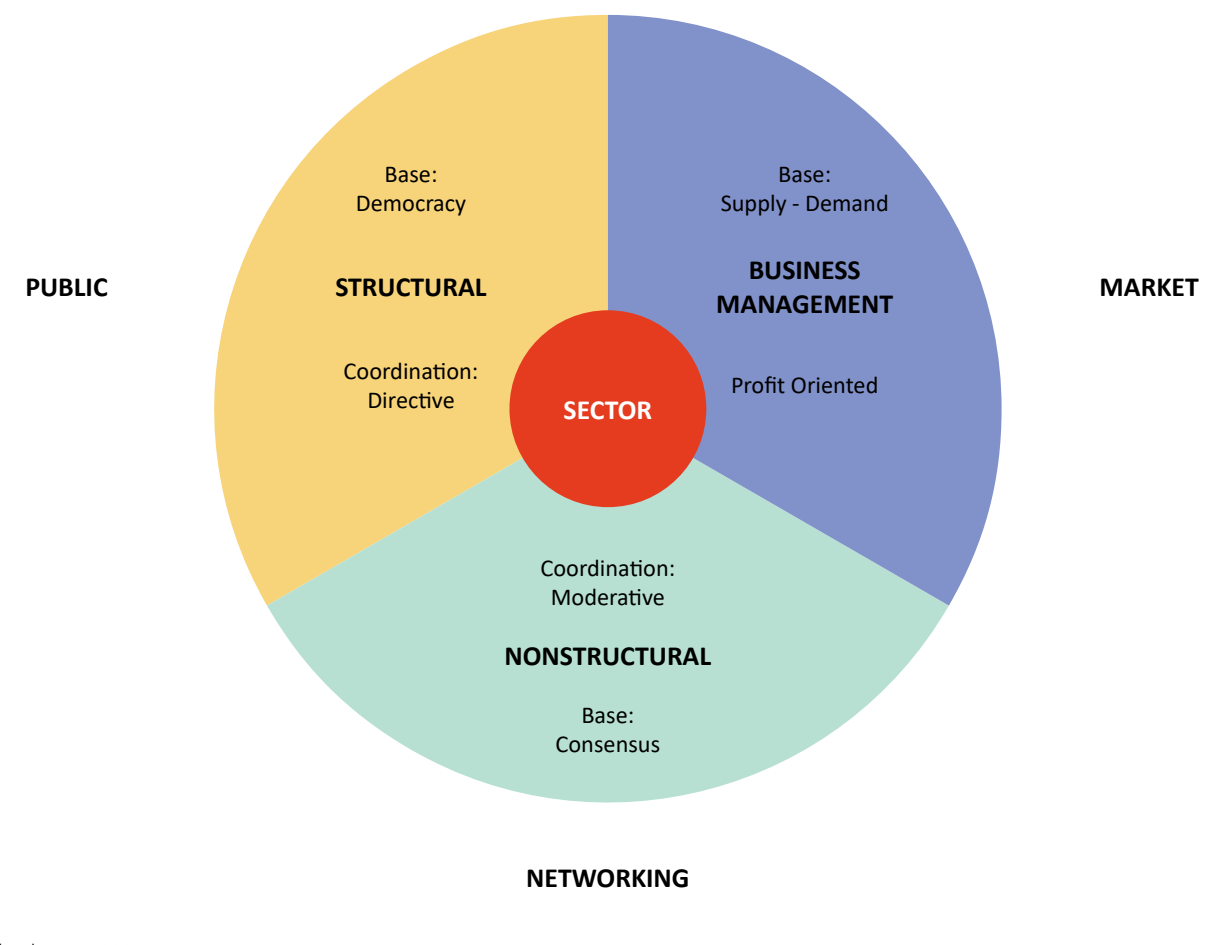

Abdurahman, 2016

Figure 4. Management Dimension in Development; Structural, Non-Structural, and Business

This is a commonly used mechanism because of the hierarchical arrangement built into its management structure. Another characteristic is the centralized budgetary intervention of the public sector, particularly the government. The example of the organizational structure of BOP can be seen in Indonesian Presidential Regulation Number 49 of 2016 on Tourism Area Management Authority of Lake Toba. The existence of professional and noncivil servant elements within the BOP structure is attached to the established signs (i.e. appointment by Ministerial Decree or related officials) and thus remains in the structural dimension. BOP function here is understood to be coordinative and authoritative. The coordination includes stakeholder relations with regional limitation according to KSPN delineation.

The figure above shows the utilization of two dimensions of management at Lake Toba and its surroundings BOP consists of Steering Committee and Management Board in the form of Public Service Board (BLU). If the Steering Board is very strong with a structural hierarchical pattern, then through the BLU is expected to take advantage of its position in the market dimension to move more dynamic and flexible. Although in carrying out the duties and functions, the Implementing Agency is directed to pay attention to the aspirations, culture, and inputs of the people in the Lake Toba Tourism Area, there is no available aspiration reservoir institution integrated into BOP. The 2-dimensional integration of the management is still faced with $3 \mathrm{~K}$ difficulties with the community and private groups. In the above pattern, has not seen an aspiration platform filled by various elements/groups of societies, private, academic, media, and public sector for moderate coordination to be done.

From the description of the above institutional pattern, it shows that the Authority Management Agency of Lake Toba Tourism Area is not a new breakthrough in the practice of development and management of the region in Indonesia. It is characterized by its characteristic that is still dominated by a hierarchical-structural pattern with procedural-formal implementation characteristics. The existence of BLU as a professional Exhibition Agency is limited as a policy implementer present through a coordinative directive pattern.

\section{DMO Utilization}

If the 'manager' of the region is agreed as one component in a tourism destination governance system, it is necessary to share the roles and functions of each related development actors. Thus, the aspects of the governance of tourism areas become relevant to be discussed as an umbrella concept of development. In the context of DECISION-MAKING, it is important to pay attention to $3 \mathrm{~K}$ aspects as the key to successful development. Each of the development actors is from the public, private, community, college, and media sectors (Penta helix, Tourism Minister Regulation, 2016, 16) will share roles and functions according to their main tasks and functions from central to local levels. 


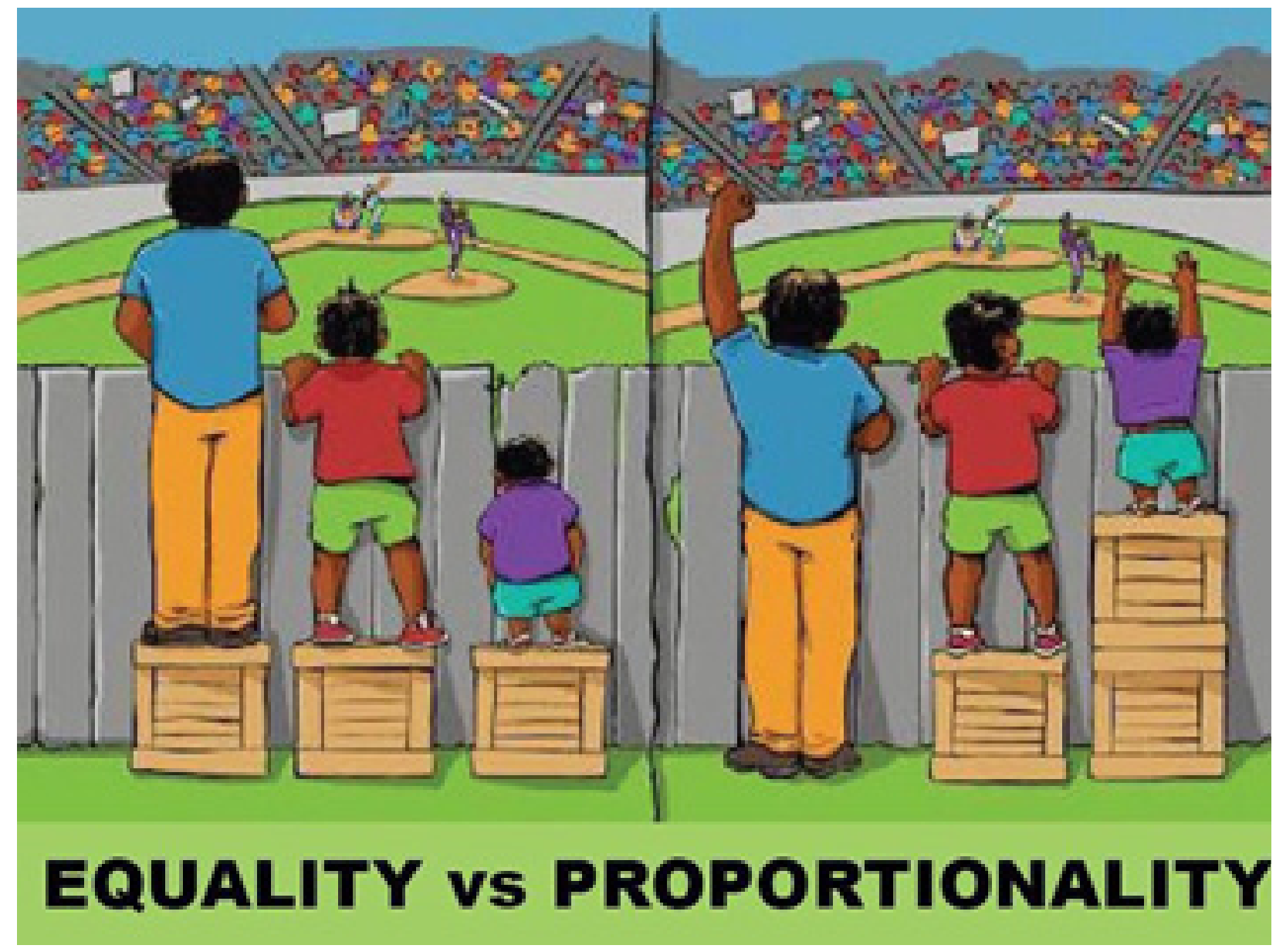

Figure 5. Equality Vs. Proportionality Illustration

The figure above shows that each management dimension has its own basic $3 \mathrm{~K}$ pattern, then understanding the position of each component needs to be done. For example, the government institution that is determined to lie in the public dimension means having the characteristics of structural management. In this dimension, coordination is usually done with a directive pattern. The hierarchical structure also fosters a bureaucratic pattern with formal-procedural communication. On the other hand, institutions with heterarchic patterns (networks) are in the nonstructural management dimension by promoting interpersonal communication. The consensus mechanism in decision-making on nonstructural dimensions is one of its distinctive characteristics (Bovaird, 2005).

Contrary to the structural dimension present through the democratic process (read: the decision process by majority vote), the management of nonstructural dimensions prioritizes the win-win solution process. The negotiation aspect among the stakeholders is a critical factor in reaching consensus. The aspect of cooperation in these two dimensions of management is different. In the structural dimension, 'cooperation' is an obligation that cannot be denied based on the hierarchical position of reference in the organizational structure. The nonstructural institutional structure is networked in which each element is in an equal position. But the equalization does not necessarily mean that each element is assured of a uniform contribution. The factor of proportionality according to the needs and capabilities of each element involved becomes important in this regard.

Figure 5 illustrates that equality does not necessarily reflect the aspect of justice. The facilities required by each party may be different. Capacity limitations here become one of the benchmarks to consider. This situation shows that equality must also consider the aspect of proportionality to fulfill the principle of justice. The process of 'dialogue' and 'negotiation' in communicating become a central aspect of management in nonstructural dimensions. The pattern of utilizing management integration from public, private, and public elements is also known as collaborative governance practice (Ansell $\&$ Gash, 2008). Because the decision-making process of this pattern is collective and consensus-based, it is in the institutional context that it belongs to the non- 
Table 2.

Management Characteristic Difference between SEZ and BOP with DMO

\begin{tabular}{|c|c|c|}
\hline & SEZ \& BOP & $\begin{array}{l}\text { DESTINATION MANAGEMENT } \\
\text { ORGANIZATION ( DMO) }\end{array}$ \\
\hline COORDINATION PATTERN & $\begin{array}{l}\text { - Directive } \\
\text { - Authoritative in its working area }\end{array}$ & - Moderative \\
\hline RELATION & $\begin{array}{l}\text { Directive through directions; Boils } \\
\text { down to Policy; } \\
\text { - Formal relationship }\end{array}$ & $\begin{array}{l}\text { - Dialogic discussion, exchanging } \\
\text { opinions/information \& } \\
\text { negotiation; Boils down to } \\
\text { Commitment; } \\
\text { - Informal relationship }\end{array}$ \\
\hline INSTITUTIONAL PATTERN & $\begin{array}{l}\text { Procedures, bureaucratic, } \\
\text { administrative, innovation can use } \\
\text { the professional components of } \\
\text { the utilization of two dimensions of } \\
\text { management, namely structural and } \\
\text { business }\end{array}$ & $\begin{array}{l}\text { Network of Executors and } \\
\text { Management professionals; } \\
\text { The utilization of } 3 \text { dimensions } \\
\text { of management, i.e. structural, } \\
\text { nonstructural \& business }\end{array}$ \\
\hline LEGALITY & Regulation \& Policy (ex mandato) & $\begin{array}{l}\text { Regulations \& Policies are } \\
\text { strengthened by mutual agreement } \\
\text { and Decision with related actors (ex } \\
\text { mera motu) }\end{array}$ \\
\hline SPATIAL & $\begin{array}{l}\text { - Generalization in the context of } \\
\text { the implementation of certain } \\
\text { coordinative functions and limits of } \\
\text { space (work area) in the context of } \\
\text { 'authoritative management' } \\
\text { - Authority of spatial management by } \\
\text { authorized institution. }\end{array}$ & $\begin{array}{l}\text { - Certain limits of space correspond } \\
\text { to local potential (endogenous) } \\
\text { and synergy in the framework of } \\
\text { 'governance' of development } \\
\text { - Building on the concept of joint } \\
\text { 'spatial governance' that contains } \\
\text { the division of roles according to } \\
\text { tupoksi (main tasks \& functions) }\end{array}$ \\
\hline ACTIVITY ORIENTATION & $\begin{array}{l}\text { Guided by formal development policy } \\
\text { and planning }\end{array}$ & $\begin{array}{l}\text { Guided by formal product planning \& } \\
\text { joint program agreement. }\end{array}$ \\
\hline OBJECTIVES & $\begin{array}{l}\text { The objectives are defined in the blue } \\
\text { print }\end{array}$ & $\begin{array}{l}\text { The objectives are relatively open, } \\
\text { because the corridor is wider \& } \\
\text { through a multi-validation process }\end{array}$ \\
\hline COMMUNICATION PROCESS & $\begin{array}{l}\text { Decisions occur through formal stages } \\
\text { and procedures. }\end{array}$ & $\begin{array}{l}\text { A 'round table' pattern, dialogue, and } \\
\text { negotiation. }\end{array}$ \\
\hline DECISION-MAKING PROCESS & Authorities and formal mechanisms & Consensus of the actors \\
\hline FINANCE & $\begin{array}{l}\text { Central Budget which has been } \\
\text { determined and provided by the State } \\
\text { Budget }\end{array}$ & $\begin{array}{l}\text { Participatory Budget among related } \\
\text { members \& from other funding } \\
\text { sources, including APBN and APBD. }\end{array}$ \\
\hline PLANNING PROCESS & Unilinear & Parallel \\
\hline LOCATION SAMPLES & $\begin{array}{l}\text { i.e. BOP of Lake Toba (North } \\
\text { Sumatera), SEZ of Tanjung Lesung } \\
\text { (Banten), SEZ of Morotai (North } \\
\text { Maluku), etc. }\end{array}$ & $\begin{array}{l}\text { i.e. DMO of Musi (Palembang City), } \\
\text { DMO of Tanjung Lesung (Banten), DMO } \\
\text { of Pangandaran (West Java), etc. }\end{array}$ \\
\hline
\end{tabular}

Source: Benjamin Abdurahman, 2017

structural management dimension. The institutional representation of this joint platform is embodied in the form of forums. The use of forums as one of the elements in the decision-making process is the hallmark of collaborative management (Bradley, 2012). More open (transparent) and accountable processes are the characteristics of countries that achieve growth in their welfare aspects (Acemoglu 


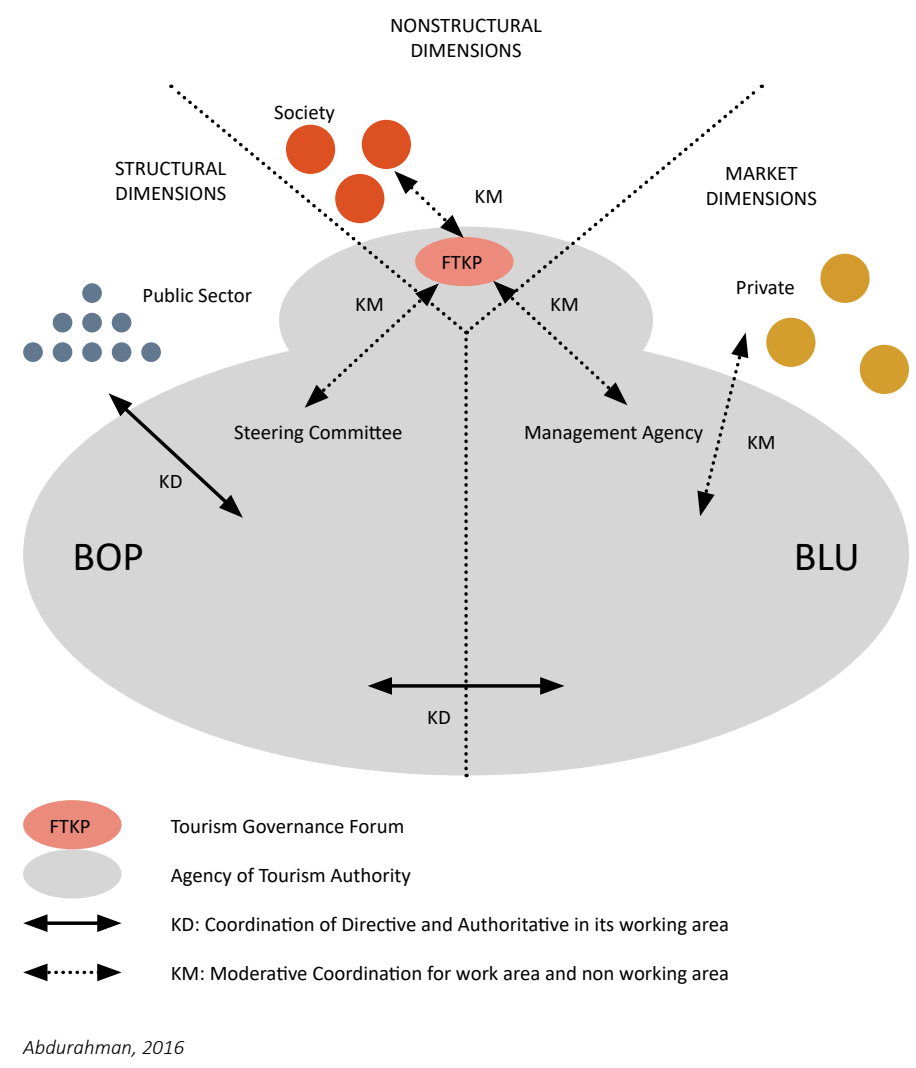

Figure 6. Integration of 3 Dimensions of Management in the Context of BOP throughout the National Priority KSPN

\section{\& Robinson, 2012).}

Based on the above description, we can see the different understanding of the coordination aspect between the management of structural and non-structural dimensions. In structuralhierarchical management, coordination has directive role and function (coordination-directive) while the nonstructural management is moderative (coordinative-moderative). Currently, there are about 25 KSPNs that have been socialized with DMO pattern. To show the differences of each approach pattern can be seen in Table 2 .

The utilization of each characteristic of management according to its dimension has advantages and disadvantages. Both models need to be seen in the context of duality (reciprocity) and not in the perspective of dualism (opposition). Both are synergized to support the creation of SEZ with $3 \mathrm{~K}$ in a sustainable regional governance system. On the one hand, structural management has a strong formal legitimacy while nonstructural management can act as a cross-agency dialogue platform with a fluid communication pattern. The utilization of management on the non-structural dimension of the DMO model as a liaison instrument in achieving $3 \mathrm{~K}$ to be more effective becomes relevant. Therefore, the use of DMO as a part of BOP and SEZ governance system becomes relevant.

\section{Conclusion}

The utilization of the three dimensions of management within a tourism governance system of tourism destinations becomes important to note. The dominance of structural management patterns, such as through BOP alone will be difficult to overcome the $3 \mathrm{~K}$ problems in the development of a destination area involving multi-actors and sectors. The combination of the three management patterns to achieve the effectiveness and efficiency of the development of the concerned area is described as Figure 6.

The integration of the three dimensions of management needs to be considered to enter the regional development governance system. Complementary principles and mutual support with each other are expected to improve the effectiveness of development performance. Tourism Governance Forum (FTKP), which is a central element in the concept of DMO in Indonesia, serves as an interface that connects all relevant actors and stakeholders. Its main task is to identify common issues and develop common concepts that form the basis for the division of roles according to the function of each actor. Thus, BOP as a component with strong formal legitimacy will make it easier to develop policies and promote regulatory improvements to be more targeted and effective. On the other hand, the Management Agency (BP) through the BLU can 
run the management of tourism area according to professional business rules. Figure 6 above shows the originality of the findings of this study which shows the use of FTKP as a component of DMO in its role in a regional tourism governance system.

The determination of BOP formation can be seen as the government effort to streamline integrated development intervention in the regional tourism area. However, strengthening the management pattern on the structural dimension alone will again be faced with the various accompanying classical weaknesses, especially in $3 \mathrm{~K}$ aspects. Therefore, integrating it by taking advantage of nonstructural and business management patterns becomes a condicio sine qua non. Each Authority Agency still needs a nonstructural patterned interface as a companion that is able to strengthen $3 \mathrm{~K}$ aspects in regional development. This can be realized through institutional use, such as FTKP, as part of the DMO approach.

The existence of non-structural institutions in the context of tourism destination governance as a catalyst of the various components involved is even more relevant to the 'overlapping' situation of regulations and policies. Nonstructural institutions are more likely to bridge the existing problems through moderation and dialogical mediation. Through the utilization of nonstructural platforms, opened the chance of obtaining a breakthrough in answering the actual problems in the field.

Strengthening coordination across sectors and actors through single destination - single management approach by strengthening institutional structural dimensions even though combined only with actors in the (professional) market dimension, as is the case with the current BOP, certainly, it is not enough to bring any significant change. The single destination single management approach needs to be fully understood by integrating all three dimensions of management as a holistic destination governance system. Success in locating institutions according to the management dimension and simultaneously building a development communication mechanism through effective role sharing will be one of the keys to successful governance of destinations in the future.

\section{ACKNOWLEDGEMENT}

Praise for the abundance of grace and guidance of Allah SWT so that the author can implement and complete the writing for this Journal. Also, I humbly express my gratitude to:

1. Prof. Sugiono Soetomo and Prof. Yuwana Mardjuka who have provided support and input in various activities and discussion opportunities.

2. Fellow DMO observers and actors, both at the center especially the Ministry of Tourism, Ministry of Village, Development of Disadvantaged Regions, and Transmigration and in the Region for cooperation in activities, discussions, and inputs.

3. Colleagues and Staff within the scope of the Inter-regional Cooperation Development and Empowerment (LEKAD) Agency for its criticism, suggestion, and support thus far.

\section{REFERENCES}

Abdurahman, B. (2005). Pemahaman Dasar Regional Management \& Regional Marketing. Semarang: LEKAD.

Abdurahman, B. (2014a). Destination Management Organization (DMO) di Indonesia. Jurnal Kepariwisataan Indonesia, 9(2), 207229. Retrieved from http://www.lekad. org/content/destination-managementorganization-dmo-di-indonesia

Abdurahman, B. (2014b). Kelemahan Regulasi dan Kebijakan Tumpulkan Inovasi Pembangunan Daerah. Jurnal Pembangunan Daerah, II(2), 51-67. Retrieved from http://www.lekad.org/ content/kelemahan-regulasi-dan-kebijakantumpulkan-inovasi-pembangunan-daerah

Acemoglu, D., \& Robinson, J. (2012). Why Nations Fail: The Origins of Power, Prosperity, and Poverty. Crown Publishing Group.

Ansell, C., \& Gash, A. (2008). Collaborative Governance in Theory and Practice. Journal of Public Administration Research and Theory, 18(4), 543-571. Retrieved from http://dx.doi. org/10.1093/jopart/mum032

Arikunto, S. (2006). Prosedur Penelitian: Suatu Pendekatan Praktek. Jakarta: Rineka Cipta.

Baldwin, R., Cave, M., \& Lodge, M. (2011). Understanding Regulation: Theory, Strategy, and Practice (2nd ed.). OUP Oxford.

Bovaird, T. (2005). Public Governance: Balancing Stakeholder Power in a Network Society. International Review of Administrative Sciences, 71(2), 217-228. http://doi. org/10.1177/0020852305053881

Bradley, Q. (2012). A "Performative" Social Movement: The Emergence of Collective Contentions within Collaborative Governance. Space and Polity, 16(2), 215-232. http://doi.or g/10.1080/13562576.2012.721504

Chandara, S. (2016, January 6). Angkor visitor numbers flat in 2015. Phnompenhpost.com. Retrieved from http://www.phnompenhpost. com/business / angkor-visitor-numbersflat-2015

Decree of the President of the Republic of Indonesia Number 150 of 2000 on Integrated Economic Development Zone, Pub. L. No. 150 (2000). Indonesia. 
Decree of the President of the Republic of Indonesia Number 41 of 1973 on Batam Island Industrial Area, Pub. L. No. 41 (1973). Indonesia.

Dewi, L. G. L. K. (2013). Usaha Pemberdayaan Sosial Ekonomi Masyarakat Desa Beraban dalam Pengelolaan Tanah Lot Secara Berkelanjutan. Analisis Pariwisata, 13(1), 32-44. Retrieved from http://fpar.unud.ac.id/ind/jurnalpariwisata-vol-13-no-1-2013/

Dwi, A. (2016). Pengelolaan Borobudur oleh Badan Otoritas Mendapat Tanggapan Positif. Kabarmagelang.com. Magelang. Retrieved from http://www.kabarmagelang.com/2016/01/ pengelolaan-borobudur-oleh-badan.html

Fikri, R. (2016, May 25). Ribuan Warga Wakatobi Demo Tolak Badan Otorita Pariwisata. Tempo. co. Kendari. Retrieved from https://m.tempo. co/read/news/2016/05/25/058774019/ ribuan-warga-wakatobi-demo-tolak-badanotorita-pariwisata

Ibrahim, J. (2005). Teori \& Metodologi Penelitian Hukum Normatif. Malang: Bayumedia Publishing.

Indonesian Presidential Regulation Number 176 of 2014 on the Liquidation Board of Aviation and Space Agency of the Republic of Indonesia, Institute for Coordination and Control Improvement of Social Welfare of Persons with Disabilities, the Council of the, Pub. L. No. 176 (2014). Indonesia.

Law of the Republic of Indonesia Number 23 of 2014 on Regional Government, Pub. L. No. 23 (2014). Indonesia.

Law of the Republic of Indonesia Number 39 of 2009 on Special Economic Zones., Pub. L. No. 39 (2009). Indonesia.

Metrotvnews.com. (2016). Menteri Pariwisata Kecewa Rendahnya Peringkat Pembangunan Pariwisata Indonesia. Retrieved from http://ekonomi.metrotvnews.com/mikro/ nN9G50jk-menteri-pariwisata-kecewarendahnya-peringkat-pembangunan- pariwisata-indonesia

Ministry of Tourism. (2014). Buku Pedoman Pengembangan Tata Kelola Destinasi Pariwisata berbasis Destination Management Organization (DMO) dan Destination Governance (DG).

Nationalgeographic.com. (2010). World Heritage Site Pictures: Taj Mahal. Retrieved from http:// www.nationalgeographic.com/travel/worldheritage/taj-mahal/\#close

Nawawi, A. (2013). Partisipasi Masyarakat dalam Pengelolaan Wisata Pantai Depok di Desa Kretek Parangtritis. Jurnal Nasional Pariwisata, 5(2), 103-109. http://doi.org/10.22146/ jnp.6370

PGI-Berita Gereja. (2016). Pimpinan Gerejagereja di Sumatera Utara: Perpres No 49 Jauh Panggang dari Api! Retrieved from http://pgi. or.id/pimpinan-gereja-gereja-di-sumaterautara-perpres-no-49-jauh-panggang-dari-api/

Razak, A. H. (2016, January 24). 2016, 3 Candi Targetkan 5,9 Juta Wisatawan. Solopos.com. Sleman. Retrieved from http://www.solopos. com/2016/01/24/wisata-sleman-2016-3candi-targetkan-59-juta-wisatawan-683974

Schumpeter, J. A. (1976). Capitalism, Socialism and Democracy. London: Allen and Unwin.

Simalungun District Regulation Number 4 of 2014 on the Organization and Work Procedure Administrator of Special Economic Zones Sei Mangkei Simalungun, Pub. L. No. 2014 (2014). Indonesia.

United Nations Industrial Development Organization. (2015). Industrial Development Report 2016. The Role of Technology and Innovation in Inclusive and Sustainable Industrial Development. Vienna.

Zeng, D. Z. (2012). SEZs in Africa: Putting the Cart in Front of Horse? Retrieved from http://blogs. worldbank.org/developmenttalk/sezs-inafrica-putting-the-cart-in-front-of-horse 